\title{
Pengaruh Model Learning Cycle Terhadap Keterampilan Proses Sains Siswa Pada Mata Pelajaran IPA Kelas III SD Negeri Harja Mekar 03 Kec. Cikarang Utara
}

\author{
Ririn Nurcholidah Anisa \\ Pascasarjana Pendidikan dasar, Universitas Negeri Jakarta \\ rhin26@gmail.com
}

\begin{abstract}
Abstrak
Penelitian ini dimaksudkan untuk mengetahui pengaruh penggunaan model learning cycle terhadap keterampilan proses sains siswa kelas III SD Negeri Harja Mekar 03 Kec. Cikarang. Penelitian ini menggunakan pendekatan kuantitatif, dengan metode penelitian quasi experiment dan desain penelitian nonequivalent control group design. Teknik pengambilan sampel menggunakan teknik sampling purposive. Populasi yang digunakan adalah 44 siswa dengan jumlah sampel kelas eksperimen 23 siswa dan kelas kontrol 21 siswa. Teknik analisis yang digunakan adalah uji-t dengan taraf signifikan 0,05 .

Hasil penelitian yang diperoleh menunjukkan bahwa nilai rata-rata posttest kelas eksperimen sebesar 82,17 lebih tinggi dibandingkan nilai rata-rata posttest kelas kontrol sebesar 79,38. Hasil dari pengujian hipotesis dengan menggunakan uji-t yang diperoleh $t_{\text {hitung }}>t_{\text {tabel }}$ yaitu 17,51 > 1,68023artinya $\mathrm{H}_{\mathrm{o}}$ ditolak dan $\mathrm{H}_{1}$ diterima. Kesimpulan yang diperoleh pada penelitian ini adalah model learning cycle memiliki pengaruh yang signifikan terhadap keterampilan proses sains siswa pada mata pelajaran IPA kelas III.
\end{abstract}

Kata Kunci : Model Learning Cycle, Keterampilan Proses Sains

\begin{abstract}
This research is intended to know the influence of the use of learning cycle model to science process skill of third grade students of SD Negeri Harja Mekar 03 Kec. Cikarang. This research uses quantitative approach, with quasi experiment research method and research design nonequivalent control group design. The sampling technique used purposive sampling technique. The population used was 44 students with the total sample class of 23 students and control class of 21 students. The analysis technique used is t-test with significant level of 0.05 .

The result of the research shows that the mean value of posttest of experimental class is 82,17 higher than the mean of posttest of control class is 79,38. The result of hypothesis testing by using t-test obtained thitung > ttable that is 17,51>1,68023artinya Ho rejected and H1 accepted. The conclusions obtained in this study is the learning cycle model has a significant influence on the science process skills of students on science subjects class III.
\end{abstract}

Keyword : Learning Cycle Model, Science Proses Skill 


\section{PENDAHULUAN}

Ilmu Pengetahuan Alam (sains) menjadi salah satu mata pelajaran pokok dalam kurikulum pendidikan di Indonesia, termasuk pada jenjang sekolah dasar. Sains berasal dari kata science yaitu istilah yang mengacu pada masalah-masalah kealaman (nature). Secara sederhana sains didefinisikan sebagai ilmu pengetahuan yang mempelajari tentang gejala-gejala alam yang dapat diklasifikasikan menjadi tiga bagian, yaitu: ilmu pengetahuan alam sebagai produk, proses, dan sikap.

Carin dan Sund dalam Sulisyiyowati (2014: 24) menyebutkan bahwa unsur sains terdiri dari tiga macam, yaitu proses, produk, dan sikap. Dalam pembelajaran sain tersedia berbagai pengalaman belajar untuk memahami konsep dan keterampilan proses sains yang berkaitan dengan kehidupan makhluk hidup. Untuk itu, dalam pembelajaran IPA terlihat keterampilan proses sains siswa dalam mendapatkan pengalaman belajar yang melibatkan keterampilan kognitif (minds on), keterampilan psikomotor (hands on), dan keterampilan afektif (hearts on).

Dahar dalam Trianto (2010: 148) mengemukakan bahwa keterampilan proses yang diajarkan dalam pendidikan IPA memberi penekanan pada keterampilan-keterampilan berpikir yang dapat berkembang pada anak-anak. Dengan menggunakan keterampilan proses, akan terjadi interaksi antara konsep/prinsip/teori yang telah ditemukan dan dikembangkan dengan pengembangan keterampilan proses itu sendiri. Melatih keterampilan proses merupakan salah satu upaya yang penting untuk memperoleh keberhasilan belajar siswa yang optimal. Materi pelajaran akan lebih mudah dipelajari, dipahami, dihayati dan diingat dalam waktu yang relatif lama bila siswa sendiri yang memperoleh pengalaman langsung dari peristiwa belajar tersebut melalui pengamatan dan eksperimen.

Namun fakta di lapangan menunjukkan bahwa kegiatan pembelajaran IPA yang dilakukan oleh guru di sekolah dasar masih terlihat monoton. Kegiatan belajar yang dilakukan masih menggunakan metode konvensional seperti metode ceramah dan metode penugasan, hal ini membuat siswa merasa bosan dan 
mengantuk serta lebih memilih berbicara sendiri dengan temannya daripada memperhatikan penjelasan dari guru. Akibatnya, siswa menjadi pasif dan kurang kreatif dalam mengikuti kegiatan pembelajaran.

Berdasarkan hasil observasi dan wawancara dengan guru kelas III di SDN Harja Mekar 03 Kec.Cikarang Utara diketahui bahwa proses pembelajaran yang berlangsung di kelas III belum melibatkan siswa dalam melatih keterampilan proses sains yang dimiliki. Sebagian besar waktu belajar siswa, dihabiskan untuk mendengarkan penjelasan guru, menghafalkan materi dan mencatat materi. Suasana kelas yang monoton, membuat siswa menjadi pasif dan kurang kreatif dalam mengikuti kegiatan pembelajaran. Hal ini menunjukkan bahwa pembelajaran IPA masih dilakukan secara transfer of knowledge sehingga pembelajaran cenderung verbal dan berorientasi pada kemampuan kognitif siswa tanpa mempertimbangkan proses untuk memperoleh pengetahuan tersebut. Pembelajaran seperti ini menyebabkan keterampilan proses sains siswa belum optimal.

Menanggapi masalah tersebut, peneliti mengharapkan adanya suatu inovasi dalam pembelajaran berupa model pembelajaran yang interaktif dan dapat membantu siswa dalam penguasaan keterampilan proses sains siswa. Salah satu inovasi pembelajaran tersebut dengan menggunakan model pembelajaran Learning Cycle. Samatowa (2011:72) mengemukakan Model Learning Cycle pertama kali dikembangkan pada tahun 1970 dalam SCIS (Science Curriculum Improvement Study), suatu program pengembangan pendidikan sains di Amerika Serikat. Dalam pelaksanaannya model Learning Cycle terdiri atas tiga fase, yaitu eksplorasi, pengenalan konsep, dan penerapan konsep. Siklus di sini diartikan bahwa tahap - tahap tersebutu dapat berulang.

Dengan model ini siswa bisa mengembangkan ide - idenya dan tidak bosan dengan pembelajaran IPA. Dalam penerapan model Learning Cycle, siswa akan ditugaskan untuk melakukan kegiatan pengamatan secara berkelompok dengan menggunakan alat serta bahan yang telah diberikan. Dengan mengikuti instruksi yang telah diberikan dalam lembar kerja, siswa akan membuat laporan hasil pengamatan serta mempresentasikan hasil pengamatan kepada siswa lainnya. 
Kegiatan tersebut akan mampu mengoptimalkan keterampilan proses sains yang dimiliki oleh siswa. Dalam Made Wena (2009 : 171-172) Lorsbach mengemukakan bahwa terdapat lima tahap dalam model Learning Cycle, yang terdiri atas : (1) Pembangkitan Minat (engagement), (2) Eksplorasi (Exploration), (3) Penjelasan (explanation), (4) Elaborasi (elaboration/extention), (5)Evaluasi (evaluation).

Berdasarkan latar belakang di atas, maka peneliti tertarik untuk melakukan penelitian untuk menunjukkan bahwa model pembelajaran Leaening Cycle dapat mempengaruhi keterampilan proses sains siswa. Dengan demikian dilakukan penelitian yang berjudul "Pengaruh Model Learning Cycle Terhadap Keterampilan Proses Sains Siswa pada Mata Pelajaran IPA Kelas III SDN Harja Mekar 03 Kec. Cikarang Utara”.

\section{METODE PENELITIAN}

Penelitian ini menggunakan metode penelitian eksperimen. Metode eksperimen adalah metode penelitian yang digunakan untuk mencari pengaruh tertentu terhadap yang lain dalam kondisi yang terkendali Sugiyono (2013:72). Desain dalam penelitian eksperimen ini adalah Quasi Experimental Design (quasi eksperimen) dengan menggunakan nonequivalent (pretest and posttest) ControlGroup Design.

Lokasi penelitian dilaksanakan di SDN Harja Mekar 03 yang beralamat di Kp. Rawa Suren Rt.10 Rw.5 Desa Harja Mekar Kecamatan Cikarang Utara Kabupaten Bekasi. Populasi dalam penelitian ini adalah siswa kelas III di SDN Harja Mekar 03 sejumlah 44 siswa dari 2 kelas yang dimiliki. Teknik pengambilan sampel yang digunakan dalam penelitian ini adalah tehnik purposive sampling, yaitu teknik penentuan sampel dengan pertimbang tertentu (Sugiyono, 2011:85).

Dalam penelitian ini terdapat dua variabel yang terdiri dari satu variabel bebas (Independent Variabel) dan satu variabel terikat (Dependent Variabel). Variabel bebas yang digunakan adalah model Learning Cycle dan variabel terikat yang digunakan adalah keterampilan proses sains siswa. 
Terdapat tiga tahapan yang dilaksanakan dalam penelitian ini, yaitu tahap awal (persiapan), tahap pelaksanaan, dan tahap akhir. Untuk mendapatkan data peneliti menggunakan instrumen lembar observasi yang di isi oleh peneliti selama pembelajaran dan setelah pembelajaran selesai. Data yang diperoleh pada penelitian ini dianalisis dengan analisis data secara deskriptif dan analisis inferensial untuk uji hipotesis. Analisis deskriptif digunakan untuk menganalisis data yang dilakukan dengan cara menyusun secara sistematis dalam bentuk angkaangka atau presentase mengenai suatu objek yang diteliti, sehingga diperoleh kesimpulan umum. Analisis inferensial digunakan untuk menguji hipotesis penelitian dengan menggunakan rumus uji-t (polled varians), namun sebelum pengujian hipotesis terlebih dahulu dilakukan perhitungan uji normalitas dengan menggunakan rumus chi kuadrat dan untuk uji homogenitas menggunakan rumus uji $\mathrm{F}$ (Fisher).

\section{HASIL DAN PEMBAHASAN}

Berdasarkan data awal dan data akhir kelas eksperimen yang telah dilaksanakan maka diketahui nilai rata-rata data awal pada kelas eksperimen sebesar 56,78 dengan persentase 40,9\% dan nilai rata-rata data akhir dari keterampilan proses sains siswa yang diajarkan dengan menggunakan menggunakan model Learning Cycle sebesar 82,17 dengan persentase 59,1\%,. Ini menunjukkan adanya peningkatan yang signifikan dari rata-rata yang telah diperoleh pada kelas eksperimen.

Tabel 1 Nilai Rata-rata Data Awal dan Data Akhir Kelas Eksperimen

\begin{tabular}{lcccc}
\hline Materi Ajar & $\begin{array}{c}\text { Rata-rata Data } \\
\text { Awal }\end{array}$ & Persentase & $\begin{array}{c}\text { Rata-rata } \\
\text { Data Akhir }\end{array}$ & Persentase \\
\hline $\begin{array}{l}\text { Perubahan Sifat } \\
\text { Benda }\end{array}$ & 56,78 & $40,9 \%$ & 82,17 & $59,1 \%$ \\
\hline
\end{tabular}

Adapun data awal dan data akhir yang diperoleh di kelas kontrol yang telah dilaksanakan maka diketahui nilai rata-rata data awal pada kelas kontrol sebesar 58,40 dengan persentase 42,3\% dan nilai rata-rata data akhir dari keterampilan proses sains siswa yang diajarkan tanpa menggunakan model Learning Cycle sebesar 79,38 dengan pesentase 57,7\%. Ini menunjukkan adanya 
peningkatan dari rata-rata yang telah diperoleh pada kelas kontrol tetapi lebih kecil daripada nilai rata-rata data akhir kelas eksperimen.

Tabel 2 Nilai Rata-rata Data Awal dan Data Akhir Kelas Kontrol

\begin{tabular}{ccccc}
\hline Materi Ajar & $\begin{array}{c}\text { Rata-rata } \\
\text { Data Awal }\end{array}$ & Persentase & $\begin{array}{c}\text { Rata-rata } \\
\text { Data Akhir }\end{array}$ & Persentase \\
\hline Perubahan Sifat Benda & 58,40 & $42,3 \%$ & 79,38 & $57,7 \%$ \\
\hline
\end{tabular}

Dengan membandingkan $x^{2}$ hitung dengan $x^{2}$ tabel pada taraf signifikan $5 \%$ diperoleh hasil $x^{2}$ hitung $\leq \mathrm{x}^{2}$ tabel, sehingga dapat disimpulkan bahwa kedua data tersebut berdistribusi normal.

Tabel 3 Hasil Perhitungan Uji Normalitas Uji Chi-Kuadrat

\begin{tabular}{ccccccc}
\hline \multirow{2}{*}{ Kelas } & \multicolumn{3}{c}{ Data Awal } & \multicolumn{3}{c}{ Data Akhir } \\
\cline { 2 - 7 } & $\mathbf{X}^{\mathbf{2}}$ hitung & $\mathbf{X}^{\mathbf{2}}$ tabel & Ket. & $\mathbf{X}^{\mathbf{2}}$ hitung & $\mathbf{X}^{\mathbf{2}}$ tabel & \multirow{2}{*}{ Ket. } \\
\hline Eksperimen & 7,26891 & 9,488 & Normal & 8,89662 & 9,488 & Normal \\
\hline Kontrol & 4,82554 & 9,488 & Normal & 1,53813 & 9,488 & Normal \\
\hline
\end{tabular}

Hasil perhitungan homogenitas pada data awal dan data akhir kedua kelas menunjukkan bahwa nilai $\mathrm{F}_{\text {hitung }} \leq \mathrm{F}_{\text {tabel }}$ dengan kata lain $\mathrm{H}_{\mathrm{o}}$ diterima, maka kedua data tersebut diperoleh menunjukkan bahwa varians homogen.

Tabel 4 Hasil Perhitungan Uji Homogenitas

\begin{tabular}{|c|c|c|c|c|c|}
\hline & \multicolumn{2}{|c|}{ Data } & \multirow{2}{*}{$\mathbf{F}_{\text {hitung }}$} & \multirow{2}{*}{$\mathbf{F}_{\text {tabel }}$} & \multirow{2}{*}{ Keterangan } \\
\hline & Eksperimen & Kontrol & & & \\
\hline Data Awal & 22,45 & 11,39 & 1,97 & 2,10 & $\begin{array}{l}\text { Kedua Data } \\
\text { Homogen }\end{array}$ \\
\hline Data Akhir & 26,87 & 19,04 & 1,411 & 2,10 & $\begin{array}{l}\text { Kedua Data } \\
\text { Homogen }\end{array}$ \\
\hline
\end{tabular}

Berdasarkan uji normalitas dan uji homogenitas yang telah dilakukan diketahui bahwa data berdistribusi normal dan homogen, maka pengujian hipotesis dilakukan dengan menggunakan uji-t rumus polled varian. Sehingga diperoleh data nilai rata-rata yang didapat di kelas eksperimen dan kontrol diketahui posttest yaitu nilai rata-rata kelas eksperimen sebesar 82,17 dan nilai rata-rata kelas kontrol sebesar 79,38. Dengan kriteria pengujian hipotesis, sebagai berikut :

1) Jika thitung $<$ ttabel, maka Ho diterima dan $\mathrm{H} 1$ ditolak

2) Jika thitung $\geq$ ttabel, maka Ho ditolak dan H1 diterima 
Dengan taraf signifikan $\alpha=0,05$ diperoleh ttabel $=1,681$, kemudian dilakukan perhitungan dengan menggunakan uji-t diperoleh thitung $=1,937$, sehingga dapat dilihat bahwa thitung $\geq$ ttabel $(1,937 \geq 1,681)$, maka Ho ditolak dan H1 diterima. Artinya terdapat perbedaan antara data akhir kelas eksperimen dengan kelas kontrol, dimana nilai rata-rata data akhir kelas eksperimen lebih besar dibandingkan dengan nilai rata-rata data akhir kelas kontrol. Hal ini menunjukkan bahwa keterampilan proses sains siswa dengan menggunakan model pembelajaran Learning Cycle lebih unggul jika dibandingkan dengan kelas yang tanpa menggunakan model Learning Cycle.

Tabel 5 Hasil Perhitungan Kelas Eksperimen dan Kelas Kontrol

\begin{tabular}{ccccc}
\hline \multicolumn{1}{c}{ Data } & $\begin{array}{c}\text { Nilai Rata- } \\
\text { Rata }\end{array}$ & $\begin{array}{c}\text { Nilai } \\
\text { thitung }\end{array}$ & $\begin{array}{c}\text { Nilai } \\
\text { ttabel }\end{array}$ & Keputusan \\
\cline { 1 - 2 } Data awal kelas eksperimen & 82,17 & \multirow{2}{*}{1,9375} & 1,68195 & H1 Diterima \\
\cline { 1 - 2 } Data akhir kelas kontrol & 79,38 & & & \\
\hline
\end{tabular}

Sumber: Hasil Penelitian 2015

Dari hasil penelitian yang dilaksanakan pada kelas kontrol maka diperoleh hasil rata-rata nilai data awal sebesar 58,40 dan nilai data akhir sebesar 79,38. Hasil pengujian hipotesis dengan menggunakan uji-t diperoleh hasil thitung $\geq$ ttabel yaitu $17,51 \geq 1,68023$, dengan tingkat signifikasi $(\alpha)<0.05$ maka $\mathrm{H}_{1}$ diterima, yang berarti terdapat pengaruh penggunaan model tersebut terhadap keterampilan proses sains siswa. Perbedaan keterampilan proses sains siswa pada kelas eksperimen dan kelas kontrol dapat dilihat pada perhitungan hipotesis data akhir kedua kelas yaitu kelas eksperimen dan kelas kontrol. menggunakan uji-t sehingga diperoleh hasil thitung $\geq$ ttabel yaitu $1,9375 \geq 1,68195$, dengan tingkat signifikasi $(\alpha)<0.05$. Dari hasil pengujian tersebut maka menunjukkan bahwa $\mathrm{H}_{0}$ ditolak dan $\mathrm{H}_{1}$ diterima, yang berarti terdapat pengaruh signifikan penggunaan model Learning Cycle terhadap keterampilan proses sains siswa.

Perbedaan keterampilan proses sains siswa pada kelas eksperimen dan kelas kontrol dapat dilihat pada perhitungan hipotesis data akhir kedua kelas yaitu kelas eksperimen dan kelas kontrol. menggunakan uji-t sehingga diperoleh hasil thitung $\geq$ ttabel yaitu $1,9375 \geq 1,68195$, dengan tingkat signifikasi $(\alpha)<0.05$. Dari hasil pengujian tersebut maka menunjukkan bahwa $\mathrm{H}_{0}$ ditolak dan $\mathrm{H}_{1}$ 
diterima, yang berarti terdapat pengaruh signifikan penggunaan model tersebut terhadap keterampilan proses sains siswa pada mata pelajaran IPA di kelas IIIA SD Negeri Harja Mekar 03.

\section{HASIL DAN PEMBAHASAN}

Berdasarkan hasil lembar observasi data awal dan data akhir untuk melihat keaadan awal dan keadaan akhir keterampilan proses sains siswa pada mata pelajaran IPA yang telah diamati pada kelas eksperimen dan kelas kontrol, maka didapatkan hasil bahwa pada kelas eksperimen terdapat selisih nilai rata-rata data awal dan data akhir sebesar 25,39\%, sedangkan pada kelas kontrol mendapatkan selisih nilai rata-rata data awal dan data akhir sebesar 20.98\%. Berdasarkan hasil tersebut dapat dilihat bahwa terdapat selisih nilai rata-rata yang lebih besar pada kelas eksperimen dibandingkan dengan kelas kontrol, yang artinya ada pengaruh penggunaan model Learning Cycle terhadap keterampilan proses sains siswa.

Hasil dari penelitian ini tentu saja berkaitan dengan perlakuan yang diberikan pada kedua kelas tersebut. Pada kelas eksperimen yang diajarkan dengan menggunakan model Learning Cycle menunjukkan proses pembelajaran yang melibatkan siswa secara aktif dan mempraktikkan secara langsung setiap proses dalam dalam kegiatan pembelajran sehingga keterampilan proses sains yang dimiliki siswa timbul selama proses pembelajaran berlangsung. Hal ini sesuai dengan pemaparan Made Wena (2010 : 172) bahwa berdasarkan tahapan model Learning Cycle yang telah dipaparkan, diharapkan siswa tidak hanya mendengarkan keterangan guru tetapi dapat berperan aktif untuk menggali, menganalisis, mengevaluasi pemahamannya terhadap konsep yang dipelajari.

Hasil penelitian ini juga diperkuat dengan penelitian yang sudah dilaksanakan sebelumnya oleh Amirul Choiri, Agus Suyudi dan Mudjihartono (2014) bahwa melalui analisis data yang diperoleh dari berbagai pembelajaran yang ada pada siswa yang diajar dengan model pembelajaran 5E-Learning Cycle dengan siswa yang diajar dengan model konvensional. Nilai rerata keterampilan proses sains siswa kelas eksperimen adalah 21,48 sementara untuk kelas kontrol adalah 18,63 dengan skor maksimal 28. 
Berdasarkan hasil ini maka hipotesis peneliti terbukti Model pembelajaran 5E-Learning Cycle memberikan perbedaan yang signifikan terhadap peningkatan keterampilan proses. Untuk itu, dengan menggunakan model Learning Cycle akan membuat siswa memiliki keterampilan proses sains yang baik dalam proses pembelajaran. Keterampilan proses sains siswa yang ditunjukkan berupa melaksanakan kegiatan obeservasi seperti menggunakan alat indra yang mereka miliki. Selain itu siswa mampu mengajukan pertanyaan baik mengenai apa yang telah dijelaskan guru atau pun temannya. Siswa juga dapat mengkomunikasikan hasil kegiatan observasinya dihadapan teman kelas lainnya. Keterampilan proses sains siswa ditunjukkan dengan keikutsertaan siswa dalam melaksanakan kegiatan observasi di dalam kelas, pengajuan pertanyaan selama kegiatan pembelajaran berlangsung, siswa mencatat setiap kegiatan penelitian yang telah dilaksanakan, menjelaskan kembali apa yang telah disampaikan guru atau temanyna, serta siswa mampu mengkomunikasikan hasil pengamatan yang sudah dilakukan.

\section{KESIMPULAN DAN SARAN}

Berdasarkan hasil penelitian ini mencakup pengaruh penggunaan model Learning Cycle terhadap keterampilan proses sains siswa pada mata pelajaran IPA di SDN Harja Mekar 03, maka dapat disimpulkan bahwa proses pembelajaran dengan menggunakan model Learning Cycle lebih berpengaruh positif terhadap keterampilan proses sains siswa pada mata pelajaran IPA kelas III SDN Harja Mekar 03. Hal ini terlihat dari nilai rata-rata keterampilan proses sains siswa pada mata pelajaran IPA yang diberikan dengan menggunakan model Learning Cycle diperoleh nilai data awal sebesar 56.78 dan nilai data akhir sebesar 82.17 dengan katalain terdapat peningkatan sebesar 25,39\%. Sedangkan nilai rata-rata keterampilan proses sains siswa pada mata pelajaran IPA yang tidak menggunakan model Learning Cycle diperoleh nilai data awal sebesar 58.40 dan nilai data akhir sebesar 79.38. Nilai rata-rata yang diperoleh oleh kelas eksperimen dengan menggunakan model Learning Cycle lebih besar 
dibandingkan dengan kelas kontrol yang diajarkan dengan tidak menggunakan model Learning Cycle.

Berdasarkan kesimpulan tersebut, peneliti memberikan beberapa saran yang sekiranya dapat dilaksanakan sekolah, guru dan siswa dalam meningkatkan keterampilan peroses sains siswa dalam pembelajaran khususnya,dan meningkatkan kualitas pembelajaran umumnya, sebagai berikut: (1) Sekolah hendaknya menyediakan sarana dan prasarana yang memadai khususnya alat kelengkapan penelitian bagi siswa agar dapat membantu siswa dalam dalam proses pembelajaran. (2) Guru diharapkan senantiasa berusaha menemukan model mengajar yang tepat untuk setiap mata pelajaran yang diberikan kepada siswa. (3) Siswa hendaknya mengikuti proses pembelajaran yang dilaksanakan oleh guru dengan menggunakan model Learning Cycle dengan semestinya sehingga keterampilan proses sains yang dimiliki siswa dapat lebih berkembang dalam proses pembelajaran.

\section{DAFTAR PUSTAKA}

Arikunto, Suharsimi. 2013. Prosedur Penelitian Suatu Pendekatan Praktik. Jakarta : Rineka Cipta.

Choiri, Amirul, Agus Suyudi dan Mudjihartono. 2014. "Pengaruh Model Pembelajaran 5E-Learning Cycles Terhadap Keterampilan Proses Sains Dan Prestasi Belajar Fisika Siswa SMA". Malang: Universitas Negeri Malang. (http://fisika.um.ac.id/download/doc_download/419artikelskripsiamirulchoir i-agussuyudi-mudjihartono.html) diakses pada 6 Desember 2017.

Rustaman, Nuryani dkk. 2010. Materi Pembelajaran IPA di SD. Jakarta: Universitas Terbuka.

Samatowa, Usman. 2011. Pembelajaran IPA di Sekolah Dasar. Jakarta: Indeks. Sani, Ridwan Abdullah. 2013. Inovasi Pembelajaran. Jakarta: Bumi Aksara.

Shoimin, Aris. 2014. 68 Model Pembelajaran Inovatif dalam Kurikulum 2013. Yogyakarta: AR - RUZZ.

Sugiyono. 2011. Metode Penelitian Kuantitatif Kualitatif dan R\&D. Bandung: Alfabeta.

Susanto, Ahmad. 2014. Teori Belajar \& Pembelajaran di Sekolah Dasar. Jakarta: Kencana.

Trianto. 2010. Model Pembelajaran Terpadu. Jakarta: Bumi Aksara. 
Wahyu Arif Murtandho. 2014. "Pengaruh Pembelajaran Learning Cycle Pada Materi Sistem Periodik Unsur Terhadap Motivasi Belajar Dan Hasil BelajarSiswa”.(http://jurnal.untan.ac.id/index.php/jpdpb/article/download/4 543/4626) Diunduh pada 6 Desember 2017.

Wena, Made. 2009. Strategi Pembelajaran Inovatif Kontemporer. Jakarta: Bumi Aksara.

Widi, Asih Wisudawati dan Eka Sulistiyowati. 2014. Metodologi Pembelajaran IPA. Jakarta: Bumi Aksara. 